\title{
FACTORS INFLUENCING PHAGOCYTOSIS OF SALMONELLA TYPHIMURIUM BY MACROPHAGES IN MURINE SCHISTOSOMIASIS
}

\author{
Maria Imaculada Muniz-Junqueira, Aluízio Prata and Carlos Eduardo Tosta
}

\begin{abstract}
We investigated the influence of Salmonella typhimurium load and specific antibodies on phagocytosis in schistosomiasis. Macrophages from Schistosoma mansoniinfected mice showed depressed capacity to increase the phagocytosis in the presence of a high bacterial load, due to a reduced involvement of these cells in phagocytosis and to a deficient ability to increase the number of phagocytosed bacteria. Normal and Salmonella-infected mice increased their phagocytic capacity when exposed to a bigh bacterial load. Antibody to Salmonella increased the phagocytic capacity of macrophages from Schistosoma-infected mice due to an increase in the number of bacteria phagocytosed but caused no modification in the number of macrophages engaged in phagocytosis. Our data indicate that macrophages from Schistosomainfected mice work close to their functional limit, since no increase in phagocytosis was observed after increasing the bacterial load. Specific antibodies can improve their phagocytic capacity and, therefore, could belp clearing concurrent infection.

Key-words: Schistosomiasis. Salmonella typhimurium. Macrophages. Phagocytosis. Chronic salmonellosis associated with schistosomiasis.
\end{abstract}

Some patients concurrently infected with Schistosoma mansoni and Salmonella develop a peculiar clinical picture recognized as chronic septicemic salmonellosis ${ }^{24} 31$. The pathogenesis of this entity is not completely understood but it has been shown that the decreased ability of macrophages to ingest and kill Salmonella may play a part in the prolonged survival of this bacteria $^{15}$. Several factors interfere with the efficiency of phagocytosis, including the effect of specific antibodies and the load of bacteria exposed to macrophages. The role played by these intervening factors in schistosomiasis is not clear.

In some experimental models, such as mice infected with Salmonella, specific antibodies

\footnotetext{
Laboratório de Imunologia Celular do Departamento de Patologia da Faculdade de Ciências da Saúde, Universidade de Brasília, Brasília, DF e Departamento de Clínica Médica da Faculdade de Medicina do Triângulo Mineiro, Uberaba, MG.

Financial support: This work was supported by grants 40.1041/85 and 40.1868/87 from CNPq. Partial support was provided by the Walter Reed Army Institute of Research, Washington, USA.

Address to: Dr ${ }^{\text {a }}$ Maria Imaculada Muniz-Junqueira. Laboratório de Imunologia Celular/Dept ${ }^{\circ}$ de Patologia/FCS/UnB. 70910-900 Brasília, DF, Brasil. Fax: (061) 233-0296.

Recebido para publicação em 27/07/96.
}

are recognized to increase phagocytosis of this bacteria $^{12}$, via the receptors for the Fc portion of $\mathrm{IgG}^{8}$. It is not known whether similar antibodies are capable to increase phagocytosis of otherwise deficient macrophages as occurs in schistosomiasis. Some other class of opsonin-independent receptors, not as yet properly characterized, but unrelated to immunoglobulin or complement, which bind oligosaccharides as mannose or glucan, also mediate phagocytosis ${ }^{18} 2630$. Phagocytosis via these later non-specific receptors would function as a first line defence mechanism, being primarily influenced by the load of bacteria. The importance of this non-immune load dependent phagocytosis in schistosomiasis has not been assessed.

The present work aimed at evaluating the influence of specific antibodies and the bacterial load on the phagocytosis of Salmonella typhimurium by peritoneal macrophages from Schistosoma mansoni-infected mice.

\section{MATERIAL AND METHODS}

To evaluate the influence of specific antibodies and the bacterial load on the phagocytosis of Salmonella typhimurium by macrophages from Schistosoma mansoniinfected mice, four groups of 5-7 months old 
Muniz-Junqueira MI, Prata A, Tosta CE. Factors influencing phagocytosis of Salmonella typhimurium by macrophages in murine schistosomiasis. Revista da Sociedade Brasileira de Medicina Tropical 30:101-106, mar-abr, 1997.

male Charles River CD1 mice (Wilmington, USA) were used. Group Sm, consisted of 25 mice infected by percutaneous route at the $30^{\text {th }}$ day of life with $50 \pm 5$ (mean $\pm \mathrm{SD}$ ) cercariae of Schistosoma mansoni per mouse; macrophages were collected 4 to 6 months later. Group St, with 17 mice intravenously inoculated with $1.5 \times 10^{5}$ colony forming units of Salmonella typhimurium per mouse one week before macrophages were tested ${ }^{15}$. Group $S m+S t$, with 8 mice infected with Schistosoma mansoni, as in group Sm, and inoculated 4 to 6 months later with Salmonella typhimurium, as in group St; macrophages were obtained one week after this second infection. Group C, with 33 non-infected mice used as normal controls. Schistosoma mansoni infection was confirmed in all animals from groups $\mathrm{Sm}$ and $\mathrm{Sm}+\mathrm{St}$ by the detection of eggs in liver specimens squashed between microscopic slides ${ }^{22}$.

Mouse macrophages obtained by washing the peritoneal cavity with $5 \mathrm{ml}$ of cold phosphate-buffered saline (PBS), $\mathrm{pH} 7.2$, were washed twice with cold PBS (400x g for $5 \mathrm{~min}$ ), individually quantified in a hemocytometer, suspended in complete RPMI 1640 medium (Gibco, Grand Island, USA), $\mathrm{pH} 7.2$, and 2x105 viable cells (viabilily always higher than 95\%) allowed to adhere onto $13 \mathrm{~mm}$ circle cover glasses in 24-well plastic plates (Linbro/Flow, McLean, USA) for two hours ${ }^{1432}$. After rinsing the cover glasses with PBS, adherent cells (> 99\% macrophages) were incubated with a suspension of Salmonella typhimurium $\left(1 \times 10^{6}\right.$ or $4 \times 10^{6}$ bacteria per well, obtained from $14 \mathrm{~h}$ cultures, quantified by spectrophotometry standardized) in RPMI 1640 with 20\% fetal calf serum (Gibco) in the presence or absence of $10 \%$ anti-Salmonella typhimurium immune serum, in a wet chamber at $37^{\circ} \mathrm{C}$ and an atmosphere of $5 \% \mathrm{CO}_{2}$ in air. Forty minutes later, cover glasses were washed with RPMI 1640 to get rid of non-phagocytosed bacteria, fixed with absolute methanol, and stained with $20 \%$ buffered Giemsa solution. The number of attached and/or ingested Salmonella typhimurium per 200 macrophages in duplicate preparations was microscopically evaluated. Microscopic fields distributed throughout the cover glass were randomly selected, and all macrophages in each field were assessed. Microscopic examination was bindly performed by the same observer (MIM-J).
The phagocytic index was calculated by the average number of bacteria ingested by macrophages multiplied by the percentage of these cells engaged in phagocytosis ${ }^{25}$.

Immune serum was obtained by subcutaneous inoculation of New Zeland white rabbits with $4 \mathrm{mg}$ dry-weigth formol-killed Salmonella typhimurium in complete Freund adjuvant. A booster dose of $1 \mathrm{mg}$ was given 15 days after and the blood obtained 8 days later. The immune serum was inactivated at $56^{\circ} \mathrm{C}$ for 30 min before used, and its potency evaluated by an agglutination test. The concentration used was selected on the basis of laboratory trials of phagocytosis using successive dilutions of the serum. Salmonella typhimurium was obtained from $14 \mathrm{~h}$ culture in Brain Heart Infusion (Difco, Detroit, USA), killed by $0.5 \%$ formaldehyde, washed three times with $\mathrm{NaCl} 0.9 \%(400 \times$ g) and dried for 6 days in a vacuum dry chamber at $37^{\circ} \mathrm{C}^{10}$.

Statistical analysis of the data were performed by the Mann-Whitney test for comparison of two unrelated non-normally distributed samples, and the Student t test when two samples showed a normal distribution, by using the SigmaStat Jandel's software package, at a significancy level of $5 \%$ $(\mathrm{p}<0.05)$.

\section{RESULTS}

Macrophages from Schistosoma mansoniinfected mice, both without or with concurrent Salmonella typhimurium infection, were unable to increase the phagocytosis when exposed to a four-fold increment in the number of Salmonella typhimurium. The median of phagocytic index from group Sm was 442 to the low bacteria load and 431 to the high bacteria load $(p>0.05)$ and for group Sm + St, 421 and 615, respectively $(p>0.05)$ (Figure 1c). Neither the number of ingested bacteria $(p>0.05)$ (Figure 1a), nor the proportion of macrophages engaged in phagocytosis showed modifications ( $p>0.05$ ) (Figure 1b). Differently, macrophages from mice infected exclusively with Salmonella typhimurium presented a high median of phagocytic index, which was subsequently increased by the exposition of these cells to an augmented load of bacteria. The median of phagocytic index was 680 to the low bacteria load and 932 to the high bacteria load $(p=0.014)$ (Figure 1c). This increase in the phagocytic index was due both to an 
Muniz-Junqueira MI, Prata A, Tosta CE. Factors influencing phagocytosis of Salmonella typhimurium by macrophages in murine schistosomiasis. Revista da Sociedade Brasileira de Medicina Tropical 30:101-106, mar-abr, 1997.

enhancement in the number of phagocytosed bacteria per macrophage (Figure 1a) and to an increase in the proportion of macrophages engaged in phagocytosis $(p=0.033)$ (Figure 1b). The same increase occurred in normal control mice (Figure 1a, b, c).

Addition of anti-Salmonella typhimurium immune serum to the system caused a significant increase in phagocytosis of macrophages from Schistosoma-infected mice subjected to a high load of bacteria (Figure 2c). This effect was due exclusively to an increase in the median of the number of phagocytosed

A
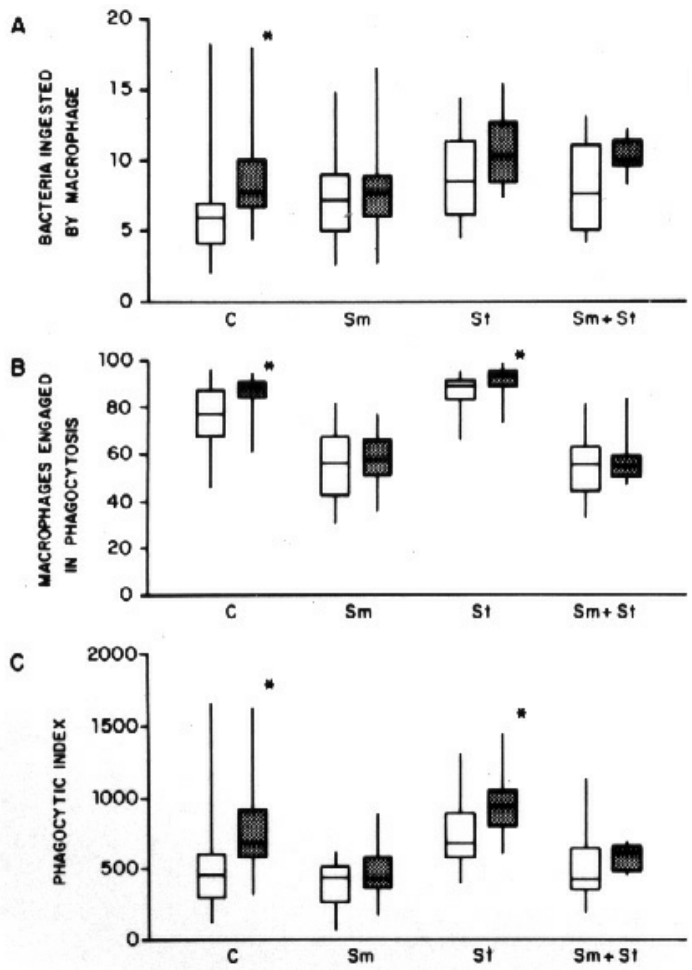

Figure 1 - Influence of the bacterial load on the phagocytosis of Salmonella typhimurium by macrophages from mice infected with Schistosoma mansoni (Sm), Salmonella typhimurium $(S t)$, both $(S m+S t)$ and normal controls (C), submitted to $1 \times 10^{6}$ (low load) Salmonella typhimurium per well (open bar) or $4 \times 10^{6}$ (bigh load) Salmonella typhimurium per well (shaded bar). Values are expressed as median, quartiles and extremes. A) Number of bacteria ingested by phagocytosing macrophage; B) Proportion of macrophages engaged in phagocytosis $(M) ; C)$ Phagocytic Index (PI)

* statistically different. Group C: p $<0.005$ (MannWhitney test); Group St : $p=0.01$ PI (low load $x$ high load) (Student t test); $\mathrm{p}=0.03, \mathrm{M}$ (low load $\mathrm{x}$ high load) (Mann-Whitney test). bacteria (7.8 to $12.5 ; \mathrm{p}=0.001$ ) (Figure $2 \mathrm{a}$ ), no modification being detected in the proportion of macrophages involved in phagocytosis $(\mathrm{p}>0.05)$ (Figure $2 \mathrm{~b})$. In the presence of a low load of bacteria, immune serum caused an increment in phagocytosis exclusively in macrophages from $S$. typhimurium-infected mice $(p=0.002)$ (Figure 3c). This occurred mainly due to an increase in the number of phagocytosed bacteria ( 8.5 to $12.6 ; \mathrm{p}=0.006$ ) (Figure 3a), no modification being detected in the proportion of macrophages engaged in phagocytosis (Figure 3b).
A
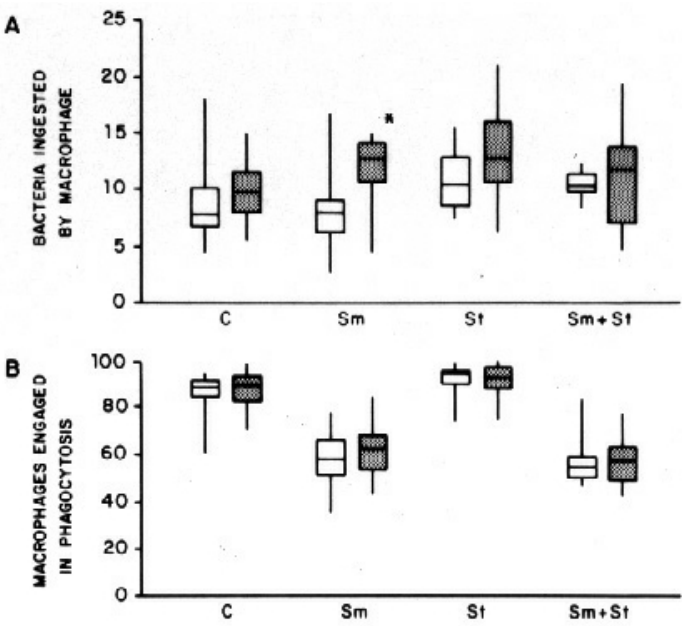

C

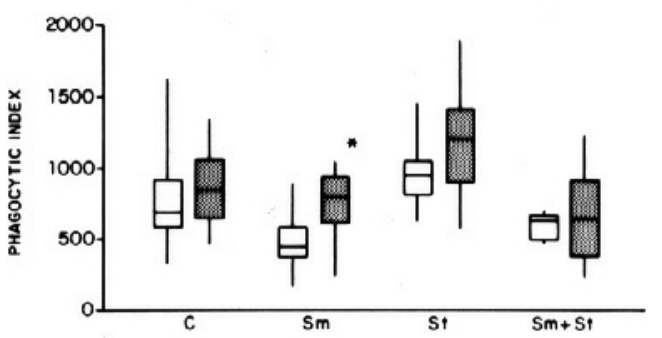

Figure 2 - Influence of antibodies against Salmonella typhimurium on the phagocytosis of this bacteria by peritoneal macrophages from mice infected with Schistosoma mansoni (Sm), Salmonella typhimurium $(S t)$, both (Sm + St) and normal controls (C). Macrophages were submitted to $4 \times 10^{6}$ bacteria per well (high load); open bar- without immune serum; shaded bar-with immune serum. Values are expressed as median quartiles and extremes. A) Number of bacteria ingested by phagocytosing macrophage; B) Proportion of macrophages engaged in phagocytosis; C) Phagocytic Index;

* statistically different. Group Sm: p $<0.001$ (Student t test) 
Muniz-Junqueira MI, Prata A, Tosta CE. Factors influencing phagocytosis of Salmonella typhimurium by macrophages in murine schistosomiasis. Revista da Sociedade Brasileira de Medicina Tropical 30:101-106, mar-abr, 1997.
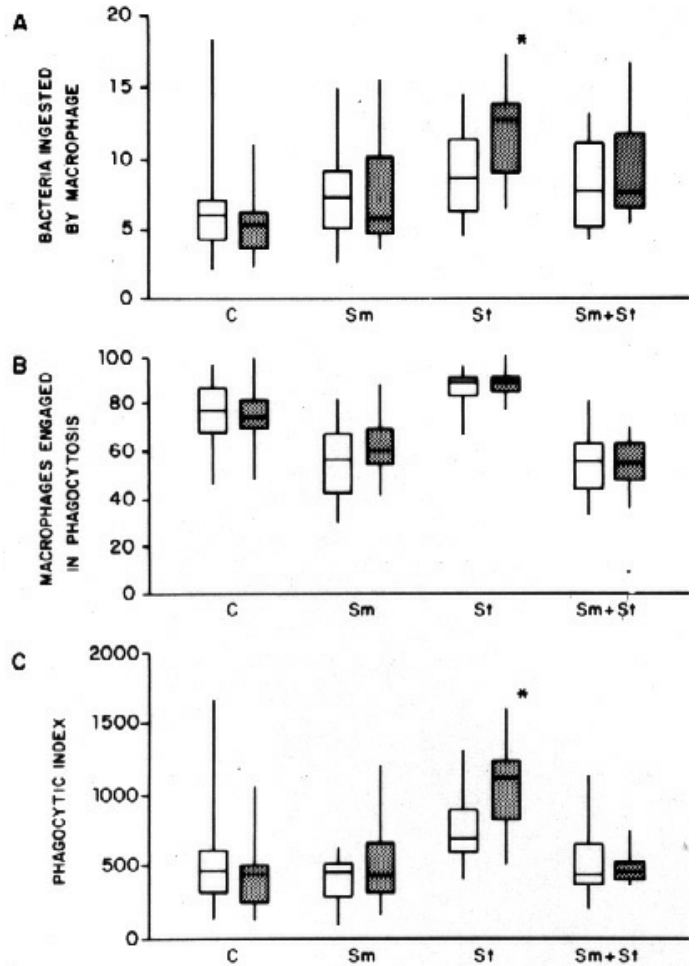

Figure 3 - Influence of antibodies against Salmonella typhimurium on the phagocytosis of this bacteria by peritoneal macrophages from mice infected with Schistosoma mansoni (Sm), Salmonella typhimurium (St), both $(\mathrm{Sm}+\mathrm{St})$ and normal controls (C). Macrophages were submitted to $1 \times 10^{\circ}$ bacteria per well (low load): open bar - without immune serum; shaded bar - with immune serum. Values are shown as median, quartiles and extremes. A) Number of bacteria ingested by phagocytosing macrophage; B) Proportion of macrophage engaged in phagocytosis; C) Phagocytic Index;

* statistically different. Group St:: p 0,006 (Student t test)

\section{DISCUSSION}

It has been recognized that macrophages play an important role in the recovery from infection by Salmonellae ${ }^{11}$. This function is enhanced by T-lymphocytes in association with the development of immunity ${ }^{1128}$. Macrophages from mice chronically infected by Schistosoma mansoni showed a deficient ability to ingest and kill Salmonella typhimurium, and this can explain the prolonged survival of this bacteria in chronic salmonellosis associated with schistosomiasis ${ }^{15}$.

The present data showed that macrophages from normal mice and from those infected with Salmonella typhimurium presented a wide functional reserve in such way that they have their phagocytic capacity enhanced upon an increase in the exposition to bacteria. Infection by Schistosoma mansoni causes an evident narrowing of this reserve, since no significant alteration of phagocytosis was detected after a four-fold increase of the bacteria load. This, is in keeping with the findings of Rocha et $\mathrm{al}^{23}$ who found an increased susceptibility of Schistosoma mansoni-infected mice to a high Salmonella load, while Collins et $\mathrm{al}^{5}$ showed normal susceptibility to a low load of Salmonella.

We found that the incapacity of macrophages from Schistosoma mansoniinfected mice to tackle with an increased demand was associated both to their inability to ingest more bacteria per cell and to increase the number of macrophages engaged in phagocytosis. It is possible that this deficiency was caused by an overall immaturity of macrophages due to the increased input of newly formed cells to the peritoneal cavity in schistosomiasis ${ }^{15} 29$. Alternatively, soluble antigens released from the worm ${ }^{21}$ or circulating immunocomplexes ${ }^{19} 27$ could occupy or internalize macrophage receptors involved in phagocytosis ${ }^{2}$. Accordingly, it has been demonstrated the presence of immunoglobulins on the surface of peritoneal macrophages collected from animals with chronic schistosomiasis ${ }^{34}$ while macrophages isolated from granulomas from infected mice showed a reduced phagocytic activity via $\mathrm{Fc}$ receptors ${ }^{33}$.

We showed that anti-Salmonella typhimurium antibodies enhanced the phagocytosis of this bacteria by macrophages from Schistosoma mansoni-infected mice, mainly due to an increase in the number of phagocytosed bacteria per macrophage. This finding indicates that these macrophages were expressing more Fc receptors on their surface, suggesting that they were elicited ${ }^{30}$ or that they displayed a certain degree of activation ${ }^{13}{ }^{34}$. However, even in the presence of antibodies to the bacteria, the phagocytic capacity of macrophages from Schistosoma mansoni-infected mice was smaller than that of non-infected animals.

We demonstrated the occurrence of a reduced phagocytic reserve of macrophages during chronic schistosomiasis, which can be partially compensated by the action of opsonizing antibodies. However, we also have previously shown in human schistosomiasis an impaired capacity to produce specific antibodies 
Muniz-Junqueira MI, Prata A, Tosta CE. Factors influencing phagocytosis of Salmonella typhimurium by macrophages in murine schistosomiasis. Revista da Sociedade Brasileira de Medicina Tropical 30:101-106, mar-abr, 1997.

to Salmonella ${ }^{16}$. Therefore, the association in schistosomiasis of a reduced functional reserve of macrophages with the impaired production of specific antibodies ${ }^{162024}$ and the deficient $\mathrm{T}$ lymphocyte function ${ }^{17}$ appear to be insufficient to overcome the Salmonella infection as seems to be the case of chronic salmonellosis associated with schistosomiasis.

\section{RESUMO}

Investigamos a influência da carga bacteriana e de anticorpos especificos sobre a fagocitose na esquistossomose. Macrófagos de camundongos esquistossomóticos mostraram uma menor capacidade para aumentar a fagocitose mesmo na presença de alta carga bacteriana, devido a um reduzido envolvimento destas células na fagocitose e a uma incapacidade para aumentar o número de bactérias fagocitadas por macrófago. Camundongos normais e infectados por Salmonella typhimurium aumentaram sua capacidade fagocitária quando expostos a uma alta carga bacteriana. Anticorpos para Salmonella typhimurium significantemente aumentaram a capacidade fagocitária de macrófagos de camundongos esquistossomóticos devido ao aumento do número de bactérias ingeridas mas não causaram nenbuma modificação no número de macrófagos envolvidos na fagocitose. Nossos dados indicam que macrófagos de camundongos esquistossomóticos trabalham próximo ao seu limite funcional, desde que nenbum aumento significante na fagocitose fo $i$ observado após aumentar a carga bacteriana. Anticorpos específicos podem melhorar sua capacidade fagocitária e, portanto, poderiam auxiliar na eliminação da infecção concomitante por Salmonella.

Palavras-chaves: Esquistossomose. Salmonelose septicêmica prolongada. Salmonella typhimurium. Macrófagos. Fagocitose.

\section{ACKNOWLEDGEMENTS}

We thanks Dr. Ernesto Hofer for his invaluable cooperation and for supplying the Salmonella typhimurium strain. The authors are also grateful to Renê de Oliveira Pires, Edno Procópio de Souza, Harley Azevedo Junior and Shigueru Ofugi for technical assistance, and José Cals da Rocha and Paulo Hipólito Bezerra Leite for the documentation.

\section{REFERENCES}

1. Blanden RV, Mackaness GB, Collins FM. Mechanisms of acquired resistance in mouse typhoid. Journal of Experimental Medicine 124:585-600, 1966.

2. Bogdan C, Nathan C. Modulation of macrophage function by transforming growth factor $\beta$, interleukin 4 and interleukin 10. In: Georgiev VS, Yamaguchi $\mathrm{H}$ (eds) Immunomodulation drugs. Annals of New York Academy of Sciences 685:713-739, 1993.

3. Capron A, Dessaint JP, Capron M, Joseph M, Torpier G. Effector mechanisms of immunity to schistosomes and their regulation. Immunological Reviews 61:41-66, 1982.

4. Capron A, Dessaint JP, Joseph M, Rosseaux R, Capron M, Bazin $\mathrm{H}$. Interaction between $\operatorname{IgE}$ complexes and macrophages in the rat: a new mechanism of macrophage activation. European Journal of Immunology 7:315-327: 1977.

5. Collins FM, Boros DL, Warren KS. The effect of Schistosoma mansoni infection on the response of mice to Salmonella enteriditis and Listeria monocytogenes. Journal of Infectious Disease 125:249-256, 1972.

6. Deelder AM, Qian ZL, Kremsner PG, Acosta L, Rabello ALT, Enyong P, Simarro PP, van Etten ECM, Krijger FW, Rotmans JP, Fillié YE, de Jonge N, Agnew AM, van Lieshout L. Quantitative diagnosis of Schistosoma infections by measurement of circulating antigens in serum and urine. Tropical and Geographical Medicine 46:233-238, 1994.

7. Greenberg S, Silverstein SC. Phagocytosis. In: Paul WE (ed) Fundamental Immunology, 3rd edition, Raven Press, New York, p. 941-964, 1993.

8. Griffin Jr FM, Bianco C, Silverstein SC. Characterization of the macrophage receptor for complement and demonstration of this functional independence from the receptor for the Fc portion of immunoglobulin G. Journal of Experimental Medicine 141:1269-1277, 1975.

9. Hsu HS, Radcliffe AS. Interactions between macrophages of guinea pigs and Salmonellae. I. Fate of Salmonella typhimurium within macrophages of normal guinea pigs. Journal of Bacteriology 96:191-197, 1968.

10. Juergens WG, Sauderson AR, Strominger JL. Chemical basis for an immunological specificity of a strain of Staphylococcus aureus. Journal of Experimental Medicine 117:925-935, 1963. 
Muniz-Junqueira MI, Prata A, Tosta CE. Factors influencing phagocytosis of Salmonella typhimurium by macrophages in murine schistosomiasis. Revista da Sociedade Brasileira de Medicina Tropical 30:101-106, mar-abr, 1997.

11. Kita E, Emoto M, Yasui K, Katsui N, Nishi K, Kashiba S. Cellular aspects of the longer-lasting immunity against mouse typhoid infection afforded by the live-cell and ribossomal vaccines. Immunology 57:431-435, 1986.

12. Mackaness GB, Blanden RV, Collins FM. Hostparasite relations in mouse typhoid. Journal of Experimental Medicine 124:573-583, 1966.

13. Mckeever PE, Spicer SS. Surface receptors of mononuclear phagocytes. In: Carr I, Daems WT (eds) The Reticuloendothelial System. A Comprehensive Treatise. Plenum, New York, p. 161-258, 1980.

14. Meltzer MS. Peritoneal mononuclear phagocytes from small animals. In: Adams DO, Edelson PJ, Koren H (eds) Methods for studying mononuclear phagocytes. Academic Press, London, p. 63-67, 1981

15. Muniz-Junqueira MI, Prata A, Tosta CE. Phagocytic and bactericidal function of mouse macrophages to Salmonella typhimurium in schistosomiasis mansoni. The American Journal of Tropical Medicine and Hygiene 46:132-136, 1992.

16. Muniz-Junqueira MI, Tavares-Neto J, Prata A, Tosta CE. Antibody response to Salmonella typhi in human schistosomiasis mansoni. Revista da Sociedade Brasileira de Medicina Tropical 29, 1996.

17. Muniz-Junqueira MI, Tosta CE, Prata A. T-cell dependent immunodepression in vivo in Schistosoma mansoni infected patients. Revista da Sociedade Brasileira de Medicina Tropical 23:27-31, 1990.

18. Munthe-Kaas AC, Kaplan G. Endocytosis by macrophages. In: Carr I, Daems WT (eds) The Reticuloendothelial System. A Comprehensive Treatise. Plenum, New York, p. 19-55, 1980.

19. Nash T, Cheever AW, Ottesen EA, Cook JA. Schistosome infections in humans: perspectives and recent findings. Annals of Internal Medicine 97:740-754, 1982.

20. Neves J, Lobo Martins NRL. Long duration of septicaemic salmonellosis: 35 cases with 12 implicated species of Salmonella. Transactions of the Royal Society of Tropical Medicine and Hygiene 61:541-552, 1967.

21. Newport GR, Colley DG. Schistosomiasis. In: Warren KS (ed) Immunology and Molecular Biology of Parasitic Infections, 3rd edition, Blackwell, Boston, p. 387- 437, 1993.

22. Prata A. Biópsia retal na esquistossomose mansoni. Bases e aplicações no diagnóstico e tratamento. Tese. Editado pelo Serviço Nacional de Educação Sanitária, Rio de Janeiro, RJ, 1957.

23. Rocha H, Castilho EA, Barreto AC, Hook EW. Características da infecção por $S$. typhimurium em camundongos infectados com S. mansoni. Gazeta Médica da Bahia 68:6-18, 1968.

24. Rocha H, Kirk JW, Hearey CD. Prolonged Salmonella bacteremia in patients with Schistosoma mansoni infection. Archives of Internal Medicine 128:254-257, 1971.

25. Shaw DR, Griffin Jr PM.Antibody dependent and antibody independent phagocytosis. In: Adams DO, Edelson PJ, Koren $\mathrm{H}$ (eds) Methods for Studying Mononuclear Phagocytes, Academic Press, London, p. 511-527, 1981.

26. Silverstein SC, Steinman RM, Cohn ZA. Endocytosis. Annual Review of Biochemistry 46:669-722, 1977.

27. Smith MD, Verroust PJ, Morel-Moroger L. A study of the presence of immunecomplexes in schistosomiasis. Transactions of the Royal Society of Tropical Medicine and Hygiene 71:343-348, 1977.

28. Smith RA, Bigley NJ. Detection of delayed hypersensitivity in mice injected with ribonucleic acid-protein fractions of Salmonella typhimurium. Infection and Immunity 6:384-389, 1972.

29. Stadecker MJ, Wright JA. Distribution and kinectics of mononuclear phagocytes in granulomas elicited by eggs of Schistosoma mansoni. American Journal of Pathology 16:245252, 1984.

30. Stein M, Keshav S.The versatility of macrophages. Clinical and Experimental Allergy 22:19-27, 1992.

31. Teixeira R.A febre tifóide de curso prolongado e o calazar (estudo comparativo). O Hospital 63:165-186, 1963.

32. van Furth R, Cohn ZA. The origen and kinectics of mononuclear phagocytes. Journal of Experimental Medicine 128:415-435, 1968.

33. Welhausen SR, Boros DL. Comparison of Fc, C3 receptors and Ia antigens on the inflamatory macrophage isolated from vigorous or immunomodulated liver granulomas of schistosome infected mice. The Journal of Reticuloendothelial Society 30:191-195, 1981.

34. Zukerman SH. Dynamics of the macrophage plasma membrane. Annual Review of Microbiology 33:267-307, 1979. 